\title{
Law Enforcement Opens Medical Records through Public Relations Media of Langsa Hospital
}

Penegakan Hukum Membuka Rekam Medis Melalui Media Humas RSUD Langsa

\author{
Tariadi; Radhali; H.S Brahmana; Eko Hadiyanto \\ email: tar_yadi27@yahoo.com
}

Universitas Sains Cut Nyak Dhien, Kuala Simpang, Kabupaten Aceh Tamiang

\begin{abstract}
Medical record is a file that contains records and documents about the patient's identity, examination, treatment, actions, and other services that have been provided to patients. This study aims to determine the legal arrangements regarding the medical record, to find out law enforcement against the Public Relations of Langsa Public Hospital publish patient medical records in online media and to find out the obstacles and efforts made in law enforcement against the Public Relations of Langsa Public Hospital that open patient medical records. The method used in this study is normative and empirical juridical. 1) In medicine, it is not permissible for a doctor or employee of a public hospital to open a medical record through the Public Relations media of Langsa Regional Hospital according to Law Number 29 of 2004 Article 51. 2) Law enforcement against someone who opens a medical record at Langsa Regional Hospital is considered ineffective because law enforcement officials, in this case, are not serious in handling cases that should be prosecuted. 3) Obstacles in law enforcement in Langsa Regional Hospital, namely that there are still overlapping laws by the police so that law enforcement cannot be carried out fairly and the efforts made in law enforcement against Langsa Regional Hospital that open medical records by means of supervision and coordination between leadership and staff in hospitals Langsa.
\end{abstract}

Keywords: Law Enforcement, Medical Records, Media

Abstrak: Rekam medis merupakan berkas yang berisi catatan dan dokumen tentang identitas pasien, pemeriksaan, pengobatan, tindakan dan pelayanan lain yang telah diberikan kepada pasien. Penelitian ini bertujuan untuk mengetahui pengaturan hukum tentang rekam medis, untuk mengetahui penegakan hukum terhadap pihak Humas RSUD Langsa mempublikasikan rekam medis pasien di media online dan untuk mengetahui hambatan dan upaya yang dilakukan dalam penegakan hukum terhadap pihak Humas RSUD Langsa yang membuka rekam medis pasien. Metode yang digunakan penelitian ini adalah yuridis normatif dan empiris. 1) Dalam medis, tidak di bolehkan bagi seorang dokter maupun pegawai rumah sakit umum untuk membuka rekam medis melalui media Humas RSUD Langsa yang atas Undang-Undang Nomor 29 Tahun 2004 Pasal 51. 2) Penegakan hukum terhadap seseorang yang membuka rekam medis di RSUD Langsa dinilai tidak efektif dikarenakan aparat penegak hukum dalam hal ini tidak serius dalam menangani kasus yang seharusnya dapat di pidanakan. 3) Hambatan dalam penegakan hukum di RSUD Langsa yaitu masih adanya timpang tindih hukum yang dilakukan oleh aparat kepolisian sehingga penegakan hukum tidak dapat dilaksanakan secara adil dan adapun upaya yang dilakukan dalam penegakan hukum terhadap pihak RSUD Langsa yang membuka rekam medis dengan cara adanya pengawasan dan koordinasi antara pimpinan dan staf di RSUD Langsa.

Kata Kunci: Penegakan Hukum, Rekam Medis, Media 


\section{PENDAHULUAN}

Rekam medis merupakan berkas yang berisi catatan dan dokumen tentang identitas pasien, pemeriksaan, pengobatan, tindakan dan pelayanan lain yang telah diberikan kepada pasien. Rekam medis ditetapkan dalam Undang-Undang Nomor 29 Tahun 2004 tentang Praktik Kedokteran, maka dalam hal ini Rekam Medis/Medical Record dijaga dalam kerahasiaannya.

Keberadaan rekam medis diperlukan dalam sarana pelayanan kesehatan, baik ditinjau dari segi pelaksanaan praktek pelayanan kesehatan maupun dari aspek hukum. Peraturan hukum yang berhubungan dengan pelaksanaan pelayanan kesehatan mencakup aspek hukum pidana, hukum perdata dan hukum administrasi. Dari aspek hukum, rekam medis dapat dipergunakan sebagai alat bukti dalam perkara hukum.

Bagian penting dalam hubungan dokter pasien adalah kepercayaan. Untuk menerima perawatan medis, seorang pasien harus membuka rahasia kepada dokter mengenai informasi yang mungkin tidak ingin diketahui orang lain. Mereka memiliki alasan yang kuat mempercayai dan mempercayakan dirinya pada dokter, hal ini terjadi karena dokter telah dinyatakan sebagai seorang professional.

Kepercayaan ini mengandalkan kompetensi dan kesediaan dokter untuk memperdulikan pasien, sehingga seorang pasien harus bisa dengan perasaan lega dan aman serta tidak khawatir menaruh kepercayaan kepada dokternya, bahwa rahasia yang diceritakan kepada dokter tidak akan diungkapkan lebih lanjut olehnya. Dengan demikian ia bebas dan sejujurnya mau menceritakan segala sesuatu yang dirasakan kepada dokter.

Hak atas rahasia medis adalah hak pasien untuk meminta agar rahasia yang diceritakan kepada dokter tidak diungkapkan lebih lanjut. Namun pasien juga bisa mengizinkan sang dokter untuk mengungkapkan kepada pihak yang berkepentingan. ${ }^{1}$ Pasien pun bisa melepaskan haknya untuk memperoleh informasi sehingga memutuskan untuk tidak diberitahukan apa yang dideritanya.

Dalam penjelasannya disebutkan bahwa Setiap orang harus dapat meminta pertolongan kedokteran dengan perasaan aman dan bebas.la harus dapat menceritakan dengan hati terbuka segala keluhan yang mengganggunya, baik bersifat jasmaniah maupun rohaniah, dengan keyakinan bahwa hak itu berguna untuk menyembuhkan dirinya. la tidak boleh merasa khawatir bahwa segala sesuatu mengenai keadaannya akan disampaikan kepada orang lain, baik oleh dokter maupun oleh petugas kedokteran yang bekerja sama dengan dokter tersebut.

Pada dasarnya informasi yang bersumber dari rekam medis dapat dibedakan dalam dua kategori, antara lain ${ }^{2}$

1. Informasi yang mengandung nilai kerahasiaan

Informasi yang mengandung nilai kerahasiaan disini meliputi semua laporan atau catatan yang terdapat dalam berkas rekam medis sebagai hasil pemeriksaan, pengobatan, observasi atau wawancara dengan pasien. Informasi ini tidak boleh disebarluaskan kepada pihak-pihak yang tidak berwenang, karena menyangkut individu langsung si pasien. Walaupun begitu, perlu diketahui pula bahwa pemberitahuan keadaan pasien

\footnotetext{
${ }^{1} \mathrm{Http}: / /$ www.hukumonline.com/klinik/detail/lt51fe16f7d4473/hak-pasien-dan-keluarganya-atas-rekam-medis

2 Departemen Kesehatan RI, 1997, Pedoman Pengelolaan RM Rumah Sakit Di Indonesia, Dirjen Pelayanan Medik, Jakarta
} 
kepada pasien maupun keluarganya oleh orang rumah sakit selain dokter yang merawat sama sekali tidak diperkenankan. Pemberitahuan menyangkut penyakit pasien kepada pasien/keluarga menjadi tanggung jawab dokter pasien, pihak lain tidak memiliki hak sama sekali.

2. Informasi yang tidak mengandung nilai kerahasiaan

Informasi yang tidak mengandung nilai kerahasiaan yang dimaksud adalah perihal identitas (nama, alamat, dan lain lain) serta informasi yang tidak mengandung nilai medis. Lazimnya, informasi jenis ini terdapat dalam lembaran paling depan berkas rekam medis rawat jalan maupun rawat inap.

Pasal 51 Dokter atau dokter gigi dalam melaksanakan praktik kedokteran mempunyai kewajiban :

a. memberikan pelayanan medis sesuai dengan standar profesi dan standar prosedur operasional serta kebutuhan medis pasien;

b. merujuk pasien ke dokter atau dokter gigi lain yang mempunyai keahlian atau kemampuan yang lebih baik, apabila tidak mampu melakukan suatu pemeriksaan atau pengobatan;

c. merahasiakan segala sesuatu yang diketahuinya tentang pasien, bahkan juga setelah pasien itu meninggal dunia;

d. melakukan pertolongan darurat atas dasar perikemanusiaan, kecuali bila ia yakin ada orang lain yang bertugas dan mampu melakukannya; dan

e. menambah ilmu pengetahuan dan mengikuti perkembangan ilmu kedokteran atau kedokteran gigi. ${ }^{3}$

Hak atas rahasia pada hakekatnya milik pasien. Dokter harus menghormati prifasi pasien. Isi rekam medis hakikatnya di dalamnya terdapat rahasia medis adalah hak pasien.

Berdasarkan Pasal 48 Undang-Undang Nomor 29 Tahun 2004 tentang Praktik Kedokteran:

(1) Setiap dokter atau dokter gigi dalam melaksanakan praktik kedokteran wajib menyimpan rahasia kedokteran.

(2) Rahasia kedokteran dapat dibuka hanya untuk kepentingan kesehatan pasien, memenuhi permintaan aparatur penegak hukum dalam rangka penegakan hukum, permintaan pasien sendiri, atau berdasarkan ketentuan perundangundangan.

(3) Ketentuan lebih lanjut mengenai rahasia kedokteran diatur dengan Peraturan Menteri.

Dalam hal pemberian sanksi terhadap pelanggaran kerahasiaan rekam medis ini telah diatur dengan tegas dalam Pasal 79 butir c di dalam Undang-Undang Nomor 29Tahun 2004 tentang praktik kedokteran yaitu, dipidana dengan pidana kurungan paling lama 1 (satu) tahun atau denda paling banyak Rp 50.000.000 (lima puluhjuta rupiah), setiap dokter atau dokter gigi yang dengan sengaja tidak memenuhi kewajiban sebagai mana dimaksud dalam Pasal 51.

Maka dalam hal ini juga menurut ketentuan Permenkes Nomor 269/MENKES/PER/2008 pada bab IV tentang penyimpanan, pemusnahan, dan kerahasiaan pada Pasal 8 ayat (1), rekam medis pasien rawat inap di rumah sakit wajib disimpan sekurang-kurangnya untuk jangka waktu lima tahun terhitung dari tanggal terakhir pasien berobat atau di pulangkan.

3 Lihat Pasal 5 huruf c Undang-Undang Nomor 29 Tahun 2004 tentang Praktik Kedokteran. 
Dikota Langsa terdapat Rumah Sakit Umum Daerah (RSUD) Kota Langsa, seorang Staf Humas RSUD langsa membuka berkas rekam medis diduga pasien tersebut mengidap penyakit (Susp) HIV dan banyaknya virus yang masuk di syaraf pasien. la juga mengatakan untuk menjawab pertanyaan-pertanyaan pihak wartawan ada orang yang memang berkompoten sehingga awak media harus menuggu. Terkait masalah diatas oleh Staf Humas RSUD Kota Langsa yang menggambarkan ketidak propesional rumah sakit tersebut, hal itu dikarenakan bahwa hasil rekam medis tidak boleh diketahui oleh orang lain terkecuali dokter dan keluarga pasien. Maka dari itu disini penulis tertarik untuk mengangkatnya dalam bentuk karya ilmiah dengan judul "Penegakan Hukum Membuka Rekam Medis Melalui Media Humas RSUD Langsa". Penelitian Ini Bertujuan Untuk Mengetahui Penegakan Hukum Membuka Rekam Medis Melalui Media Humas RSUD Langsa dan Upaya Yang Dilakukan Dalam Penegakan Hukum Terhadap Pihak Humas Yang Membuka Rekam Medis Pasien.

\section{PERUMUSAN MASALAH}

1. Bagaimana pengaturan hukum tentang rekam medis pasien?

2. Bagaimana penegakan hukum terhadap pihak humas RSUD Langsa mempublikasikan rekam medis pasien di media online?

3. Apa hambatan dan upaya yang dilakukan dalam penegakan hukum terhadap pihak humas RSUD Langsa yang membuka rekam medis pasien?

\section{METODE PENELITIAN}

\section{Spesifikasi Penelitian}

Penelitian berarti pencarian kembali. Pencarian yang dimaksud adalah pencarian terhadap pengetahuan yang benar (ilmiah), karna hasil dari pencarian ini akan dipakai untuk menjawab permasalah tertentu. ${ }^{4}$ Agar suatu penelitian ilmiah dapat berjalan dengan baik maka perlu menggunakan suatu metode penelitian yang baik dan tepat. Metodologi merupakan suatu unsur yang mutlak harus ada di dalam penelitian dan pengembangan ilmu pengetahuan. ${ }^{5}$

\section{Metode Pendekatan}

Metode penelitian yang digunakan adalah empiris dan yuridis normatif. Jenis Penelitian yuridis normatif adalah penelitian yang dilakukan dengan cara meneliti bahan pustaka atau data sekunder. Penelitian yuridis normatif adalah penelitian yang menggunakan data sekunder. Data sekunder adalah data yang terdiri bahan hukum primer yaitu terdiri bahan-bahan hukum yang mengikat, terdiri dari Peraturan Perundang-undangan, yurispudensi dan sebagainya, sedangkan data primer terdiri dari bahan hukum sekunder yang memberi penjelasan mengenai bahan hukum primer, seperti pendapat para sarjana, dokumen- dokumen dan lain-lainnya. Bahan hukum tertier yang memberikan penjelasan terhadap bahan hukum primer dan bahan hukum sekunder, antara lain kamus, ensiklopedia dan sebagainya. ${ }^{6}$

\footnotetext{
${ }_{4}^{4}$ Amiruddin dan Zainal Asikin, 2010, Pengantar Metode Penelitian Hukum, Jakarta, Rajawali Pers, hal 19

5 Soerjono Soekanto, 2006, Pengantar Penelitian Hukum, Jakarta, Universitas Indonesia (UI-Press), hal 7 6 lbid,
} 
Sedangkan penelitian hukum empiris adalah penelitian hukum yang menggunakan data primer, yang diproleh langsung dari hasil wawancara dengan informan dan responden. Data yang digunakan dalam Penelitian ini adalah data Sekunder dan data Primer. Hal ini dikarenakan oleh spesifikasi penelitian, spesifikasi dalam penelitian ini menggunakan metode yuridis normatif dan yuridis sosiologis.

Sementara itu data primer adalah data yang diproleh langsung dari lapangan yaitu hasil wawancara dengan instansi terkait dengan penelitian.

\section{Lokasi Penelitian}

Dalam melakukan penulisian ilmiah ini, penulis melakukan Penelitian di Kota Langsa

\section{Teknik Pengumpulan Data}

Untuk memproleh data sekunder dalam penelitian ini dilakukan melalui penelusuran bahan-bahan kepustakaan atau study pustaka (Lybrary Research) yang berkaitan dengan masalah penegakan hukum membuka rekam Medis melalui media Humas RSUD. Pengumpulan bahan-bahan kepustakaan tersebut dilakukan dengan menghimpun data sekunder berupa bahan hukum primer, bahan hukum sekunder dan bahan hukum tersier.

Teknik pengumpulan data dari jenis penelitian hukum normatif dilakukan dengan cara study puska (Library research) terhadap bahan-bahan hukum tertulis yang relevan, baik terhadap bahan hukum primer, sekunder, maupun terhadap bahan hukum tersier bahkan terhadap bahan hukum non hukum. ${ }^{7}$

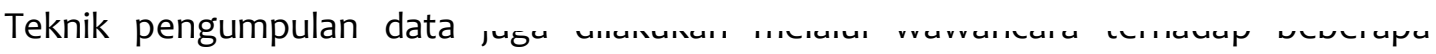
informan. Teknik pengumpulan data melalui wawancara merupakan salah satu alat pengumpulan data dalam jenis penelitian hukum. ${ }^{8}$ Adapun Responden yang diwawancara dalam penelitian ini adalah:

1. 2 (dua) orang Kepolisian

2. 2 (dua) orang Wartawan

Adapun Informan yang diwawancarai dalam penelitian ini adalah :

1. 2 (Dua) orang akademisi

\section{PEMBAHASAN}

\section{Pengaturan Hukum Tentang Rekam Medis Pasien}

Rekam medis adalah fakta yang berkaitan dengan keadaan pasien riwayat penyakit dan pengobatan masa lalu serta saat ini yang tertulis oleh profesi kesehatan yang memberikan pelayanan kepada pasien tersebut. ${ }^{9}$

Secara umum, informasi yang terdapat dalam rekam medis sifatnya rahasia. Pasien mengharapkan hal yang ditulis dokter yang bersifat rahasia bagi dirinya. Hal ini menyebabkan bila dokter merasa perlu konsultasi dengan dokter lain, harus atas

\footnotetext{
7 Mukti Fajar dan Yulianto Achmad, 2012, Dualisme penelitian hukum normatif dan Empiris, Yogyakarta, Pustaka Pelajar, hal 160

8 Ibid, hal 161

9 Ery, Rustiyanto, 2010, Statistik Rumah Sakit Untuk Pengambilan Keputusan, Edisi Pertama, Yogyakarta, Graha Ilmu, hal 6
} 
persetujuan pasien karena dalam hal demikian dokter konsultan akan membaca segala rekaman dan catatan dokter pertama. ${ }^{10}$

Kewajiban dokter dan kalangan kesehatan untuk melindungi rahasia ini tertuang dalam lafal dokter, KODEKI dan peraturan perundang-undangan yang ada tentang rahasia jabatan dan pekerjaan dokter. Rekam medis yang baru terus bertambah, sementara ruangan tempat rekam medis tidak mungkin menampung. Jalan keluar yang dapat ditempuh adalah dengan menyingkirkan sebagian dari rekam medis yang pasti diperkirakan tidak akan dipakai lagi. Suatu rencana yang pasti tentang pengelolaan rekam medis yang tidak aktif harus ditetapkan sehingga dapat tersedia tempat peyimpanan rekam medis yang baru. Dengan perkataan lain pengertian penyingkiran ini akan berhubungan dengan berapa lama rekam medis harus disimpan. ${ }^{11}$

Dasar hukum tentang penyelenggaraan rekam medis antara lain sebagai berikut :

1) PP No. 10 Tahun 1960 tentang Wajib Simpan Rahasia Kedokteran.

2) Undang-Undang Republik Indonesia Nomor 44 Tahun 2009 tentang Rumah Sakit, dimana antara lain disebutkan Kewajiban dan Hak yang tercantum dalam Pasal 29, setiap Rumah Sakit mempunyai kewajiban :

a) Memberikan informasi yang benar tentang pelayanan Rumah Sakit kepadan masyarakat.

b) Memberi pelayanan kesehatan yang aman, bermutu, anti diskriminasi, dan efektif dengan mengutamakan.

Dalam hal membuka rekam medis pihak dokter maupun terkait tidak dibenarkan membuka rekam medis kepada siapapun terkecuali kepada pihak keluarga korban dan korban. Rekam medis merupakan kerahasiaan dokter bersama pasien hal ini dilindungi oleh Undang-Undang dan tidak dapat dibuka oleh dokter demi kerahasiaan penyakit yang diderita oleh pasien tersebut. ${ }^{12}$

Pihak rumah sakit apabila membuka rekam medis tanpa seizin pasien, maka dokter akan dikenakan sanksi sesuai dengan Peraturan Perundang-undangan yang berlaku maka dari itu dokter dalam hal ini harus merahasiakan penyakit yang di derita oleh pasien terkecuali kepada ahli/keluarga pasien tersebut. ${ }^{13}$

Menurut Faisal sebenarnya dalam hal pembukaan rekam medis oleh media Humas RSUD Langsa tidak ada dasar hukum yang membolehkan membuka rekam medis pasien seperti yang ada dalam peraturan Perundang-undangan maupun Standart Operating Prosedur (SOP) yang ada di RSUD Langsa ini. ${ }^{14}$

Menurut Faisal juga menerangkan bahwa staf Humas yang mengonfirmasikan kepada media online pekan dulu tidak diketahui dan tidak atas perintah dari RSUD Langsa terkait dengan pemberitaan tersebut, maka dari itu staf Humas pada RSUD Langsa tidak berwenang mengatakan seperti yang ada di media online beberapa waktu lalu maka dari

\footnotetext{
$10 \mathrm{lbid}$

${ }^{11} \mathrm{lbid}$

${ }^{12} \mathrm{lbid}$

$13 \mathrm{lbid}$

14 Wawancara dengan dr. Faisal dokter Rumah Sakit Umum Daerah Langsa
} 
itu kami sangat menyayangkan apabila ada oknum rumah sakit yang mengatakan seperti yang ada di media online karena itu melanggar dari kode etik pihak medis. ${ }^{15}$

Menurut Fahrur Rozi terkait staf Humas yang membuka rekam medis kepada pihak media online sangat menyalahi aturan apalagi dalam hal rekam medis dokter harus mengacu kepada Perundang-undangan. ${ }^{16}$

Dari kesimpulan diatas dapat simpulkan bahwa pengaturan rekam medis pada pasien sangat dijaga kerahasiaannya dikarenakan rekam medis merupakan sesuatu yang harus dilindungi bagi pasien yang dalam hal ini tidak dapat di publikasikan untuk umum.

\section{Penegakan Hukum Terhadap Pihak RSUD Langsa Yang Mempublikasikan Rekam Medis Pasien di Media Online}

Penegakan hukum merupakan suatu usaha untuk mewujudkan ide-ide keadilan, kepastian hukum dan kemanfaatan sosial menjadi kenyataan. Jadi penegakan hukum pada hakikatnya adalah proses perwujudan ide-ide. Penegakan hukum adalah proses dilakukannya upaya tegaknya atau berfungsinya norma-norma hukum secara nyata sebagai pedoman pelaku dalam lalu lintas atau hubungan-hubungan hukum dalam kehidupan bermasyarakat dan bernegara. ${ }^{17}$

Rekam medis melalui media humas RSUD yang diketahui dalam Pasal 57 Undang-Undang Nomor 36 Tahun 2009 tentang Kesehatan mengatakan bahwa setiap orang berhak atas kondisi kesehatan pribadinya yang telah dikemukakan kepada penyelenggara pelayanan. Dan dalam Pasal 48 Undang-Undang Nomor 29 Tahun 2004 tentang Praktek kedokteran mengatakan bahwa setiap dokter atau dokter gigi dalam melaksanakan praktek kedokterannya wajib menyimpan rahasia kedokteran. Kemudian, dalam Pasal 32 (i) Undang-Undang Nomor 44 Tentang Rumah Sakit mengatakan bahwa hak pasien untuk mendapatkan privasi dan kerahasiaan penyakit yang diderita termasuk data-data medisnya.

Melihat pentingnya perlakuan non diskriminasi dan kesetaraan dalam menerima pelayanan kesehatan oleh tenaga kesehatan, keempat peraturan ini masih belum memadai dalam hak atas kesehatan bagi orang dengan HIV/AIDS, oleh karena itu dapat dikatakan bahwa peraturan-peraturan tersebut masih terdapat celah hukum yang memungkinkan terjadinya stigma dan diskriminasi. ${ }^{18}$

Maka dalam hal ini jelas bahwa dalam hal penegakan hukum terhadap seseorang yang membuka rekam medis di RSUD Langsa belum berjalan secara maksimal, di ketahui bahwa melalui pemberitaan Lintas Atjeh bahwa pihak staf Humas RSUD menerangkan penyakit yang diderita oleh pasien, padahal dalam hal ini Undang-undang tidak mengizinkan siapapun untuk membeberkan hasil rekam medis yang sudah diketahui oleh dokter maupun pihak rumah sakit. ${ }^{19}$

\footnotetext{
15 Wawancara dengan dr. Faisal dokter Rumah Sakit Umum Daerah Langsa

16 Wawancara dengan Fahrur Rozi Staf Humas dokter Rumah Sakit Umum Daerah Langsa

17 Rony Rahman Nitibaskara, 2000, Tegakkan Hukum Gunakan Hukum, Jakarta, Kompas, hal ix

18 Tyan Ferdiana Hikmah, dkk, 2019, Protection of Human Right for Pregnant Women in Implementing HIV/AIDS Screening for Prevention of HIV/AIDS transmission from mother to Child in Bantul District Health Center, SOEPRA Jurnal Hukum Kesehatan, Vol. 5 No. 1, hal 10-25

19 Wawancara dengan Hariadi wartawan online Lintas Adjeh
} 
Penegakan hukum terhadap staf Humas yang membuka rahasia dari rekam medis tidak berjalan dikarenakan berbagai alasan dari aparat kepolisian yang sudah diminta konfirmasi oleh beberapa awak media online terkait dengan pemberitaan yang di temui langsung terhadap pihak staf Humas RSUD Langsa. Penegakan hukum pada Polres Langsa terkait kasus tersebut sangat lemah dan dapat dinilai hukum hanya sebatas angan-angan yang cita-citakan meskipun staf Humas RSUD tersebut sudah mencukupi unsur tindak pidana. ${ }^{20}$

Dalam hal penegakan hukum terhadap seseorang yang membuka rekam medis melalui media humas RSUD Langsa maka perlu di tindak lanjuti demi tercapainya penegakan hukum yang berkeadilan dan tidak tumpang tindih. Maka dalam hal ini sebenarnya pihak aparat penegak hukum harus memanggil pihak terkait guna memberikan keterangan terhadap apa yang di beritakan oleh media online.

Hukum tidak hanya sebatas sesuatu yang di cita-citakan oleh apa yang sudah tercantum pada Undang-Undang Dasar Negara Republik Indonesia, tetapi hukum juga harus memiliki nilai agar dalam penegakan hukum dapat di percayakan oleh masyarakat banyak guna mencapai dari tujuan hukum tersebut.

1. Keadilan

Era sekarang ini barangkali tidak ada pekikan yang lebih lantang dari pada seruan keadilan dan seringkali orang yang menuntut keadilan berteriak dengan mengatakan dimana letak keadilan itu. Jika kita lihat teori keadilan itu maka kita akan banyak menemukan beragam macam tentang teori keadilan, mulai keadilan menurut hukum Islam, ${ }^{21}$ sampai dengan teori keadilan yang ada di kalangan berbagai pakar hukum.

2. Kepastian Hukum

Menurut Sudikno Mertukusumo 22 , kepastian hukum merupakan jaminan bahwa hukum tersebut dapat dijalankan dengan baik. Sudah tentu kepastian hukum sudah menjadi bagian yang tidak terpisahkan hal ini lebih diutamakan untuk norma hukum tertulis. Karena kepastian sendiri hakikatnya merupakan tujuan utama dari hukum. kepastian hukum ini menjadi keteraturan masyarakat berkaitan erat dengan kepastian itu sendiri karena esensi dari keteraturan akan menyebabkan seseorag hidup secara berkepastian dalam melakukan kegiatan yang diperlukan dalam melakukan aktivitas kehidupan masyarakat itu sendiri.

Dalam hal kepastian hukum ini menurut Teubner $^{23}$ hukum yang dapat memuaskan semua pihak adalah hukum yang responshif dan hukum yang responshif hanya lahir dari jika ada demokratisasi legislasi. Tanpa demokrasi (partisipasi masyarakat) dalam proses legislasi hasilnya tidak akan pernah melahirkan hukum yang mandiri. Hukum hanya sebagai legitimasi keinginan pemerintah, dalam kondisi seperti itu ada tindakan pemerintah dianggap bertentangan dengan hukum. Kepentingan-kepentingan masyarakat menjadi terabaikan karena hukum bersifat mandiri karena maknamaknanya mengacu pada dirinya sendiri (keadilan, kepastian, kemanfaatan).

3. Kemanfaatan Hukum

\footnotetext{
20 Wawancara dengan Zulhadi wartawan online Acehnews

${ }^{21}$ Asmawi, 2006, Filsafat Hukum Islam, Surabaya, eLKAF Press, hal. 45.

22 Sudikno Mertukusumo, 2009, Penemuan Hukum, Yogyakarta, Liberty, hal. 21.

${ }_{23}$ Gunther Teubner, Subtantive and Reflexsive Elements in Modern Law, Law and Social Review, Volume 17 Nomor

2. Dikutip oleh Teguh Prasetyo dan Abdul Halim, 2012, Teori, dan Ilmu Hukum, Jakarta, Raja Grafindo, hal. 317318.
} 
Kemanfaatan merupakan hal yang paling utama didalam sebuah tujuan hukum, mengenai pembahasan tujuan hukum terlebih dahulu diketahui apakah yang diartikan dengan tujuannya sendiri dan yang mempunyai tujuan hanyalah manusia akan tetapi hukum bukanlah tujuan manusia, hukum hanyalah salah satu alat untuk mencapai tujuan dalam hidup bermasyarakat dan bernegara. Tujuan hukum bisa terlihat dalam fungsinya sebagai fungsi perlindungan kepentingan manusia, hukum mempunyai sasaran yang hendak dicapai. ${ }^{24}$ Jika kita lihat defenisi manfaat dalam kamus besar bahasa Indonesia manfaat secara terminologi bisa diartikan guna atau faedah. ${ }^{25}$

\section{Hambatan dan Upaya Yang Dilakukan Dalam Penegakan Hukum Terhadap Pihak Humas RSUD Langsa Yang Membuka Rekam Medis Pasien}

a. Hambatan Yang Dilakukan Dalam Penegakan Hukum Terhadap Pihak Humas RSUD Langsa Yang Membuka Rekam Medis Pasien

Menurut Saiful bahwa hambatan dalam penegakan hukum terhadap staf Humas yang membuka rekam medis tersebut yaitu pihak yang melaporkan kejadian ini tidak ada, dalam hal penegakan hukum maka harus adanya seseorang yang melaporkan kejadian ini bermula dari permulaan bukti yang kuat, apabila terdapat pemberitaan dari pihak media maka dalam hal ini belum cukup bukti untuk melakukan pembuktian terhadap pelaku tersebut maka dari itu terhadap bocornya rekam medis yang dilakukan oleh staf Humas RSUD tidak cukup bukti untuk dilakukan penegakan hukum. ${ }^{26}$

Menurut Andi Rachmad bahwa rekam medis tidak dapat diberitakan meskipun kepada media sekaligus. Hal itu dikarenakan bahwa hasil rekam medis tidak boleh diketahui oleh orang lain terkecuali dokter dan keluarga pasien. Karena, rahasia medis merupakan hak pasien yang harus dilindungi dan dijunjung tinggi oleh setiap penyelenggara pelayanan kesehatan. Pelanggaran terhadap hak pasien ini merupakan sebuah kejahatan yang dapat dimintai pertanggung jawaban hukum.

Perlu diketahui bahwa perlindungan terhadap hak rahasia medis ini dapat di lihat dalam peraturan perundang-undangan antara lain, Pasal 57 Undang-Undang Nomor 36 tahun 2009 tentang Kesehatan mengatakan bahwa setiap orang berhak atas kondisi kesehatan pribadinya yang telah dikemukakan kepada penyelenggara pelayanan. Dan dalam Pasal 48 Undang-Undang Nomor 29 Tahun 2004 tentang Praktek kedokteran mengatakan bahwa setiap dokter atau dokter gigi dalam melaksanakan praktek kedokterannya wajib menyimpan rahasia kedokteran. Kemudian, dalam Pasal 32 (i) Undang-Undang Nomor 44 tentang Rumah Sakit mengatakan bahwa hak pasien untuk mendapatkan privasi dan kerahasiaan penyakit yang diderita termasuk data-data medisnya.

Sehingga, apa yang dibeberkan Staf Humas RSUD Langsa tersebut merupakan pelanggaran terhadap ketentuan perundang-undangan tersebut diancam pidana kurungan badan sebagai mana yang diatur dalam Pasal 322 KUHP yang menyebutkan, barang siapa yang dengan sengaja membuka rahasia yang wajib ia simpan karena jabatannya atau karena pekerjaannya, baik yang sekarang maupun yang dahulu,

\footnotetext{
${ }^{24}$ Said Sampara dkk, 2011, Pengantar Ilmu Hukum, Yogyakarta, Total Media, hal 40

$25 \mathrm{KBBI}$, http://kbbi.web.id/manfaat

${ }^{26}$ Wawancara dengan Bripka Saiful Penyidik Polres Langsa
} 
dihukum dengan hukuman penjara selama-lamanya sembilan bulan atau denda sebanyak-banyaknya sembilan ribu rupiah. ${ }^{27}$

Hambatan yang dilakukan dalam penegakan hukum di sini yaitu pihak aparat kepolisian tidak menerima laporan dari pada korban yang dimaksud maka dari itu dalam penanganan penegakan hukumnya maka pihak kepolisian tidak dapat memproses secara lanjut dalam penanganannya. ${ }^{28}$

Menurut Pasal 46 Undang-Undang Nomor 44 Tahun 2009 tentang Rumah Sakit, maka dalam hal ini rumah sakit betanggung jawab secara hukum terhadap semua kerugian yang ditimbulkan atas kelalaian yang dilakukan oleh tenaga kesehatan di rumah sakit.

b. Upaya Yang Dilakukan Dalam Penegakan Hukum Terhadap Pihak Humas RSUD Langsa Yang Membuka Rekam Medis Paien

Penegakan hukum terhadap bocornya rekam medis yang diberitakan melalui Humas RSUD Langsa seharusnya harus ditindak lanjut oleh aparat penegak hukum yaitu kepolisian. Dalam hal ini menurut Zamzami bahwa bocornya rekam medis yang ditulis oleh lintas atjeh tidak memenuhi unsur pidana dikarenakan dalam hal ini staf Humas RSUD tidak memberikan rekam medis tersebut kepada pihak wartawan, artinya staf Humas RSUD Langsa hanya menerangkan penyakit yang mengakibatkan pasien meninggal dunia. ${ }^{29}$

Sementara upaya dalam penegakan hukum terhadap pihak RSUD Langsa dalam hal membuka rekam medis maka perlu dikaji ulang meskipun demikian aparat penegak hukum mapun pemerintah perlu melakukan pengawasan terhadap Staf maupun Dokter yang bertugas di Rumah Sakit Umum Daerah Langsa.

Ada beberapa upaya yang dilakukan oleh penegakan hukum terhadap pihak RSUD Langsa :

1. Pengawasan

Menurut Harahap bahwa pengawasan merupakan suatu cara yang digunakan seorang atasan untuk mengawasi anak buahnya. Sama halnya dengan Simbolon, pengawasan merupakan hal penting dimana pimpinan atau manajer ingin mengevaluasi hasil pekerjaan stafnya. Dessler, menyatakan juga bahwa pengawasan merupakan sebuah tindakan untuk mengoreksi terhadap hal-hal yang dilakukan. ${ }^{30}$

Pengawasan terhadap bawahan baik itu dokter maupun struktural dari pihak RSUD yaitu pihak Humas dalam hal ini pengawasan yang dilakukan apabila ada beberapa kasus di RSUD maka dalam hal ini Humas harus mengkinfirmasi pimpinan RSUD terkait dalam hal penyampaian baik itu dalam pemberitaan maupun hal lain yang ingin di konfirmasi melalui bagian Humas.

\footnotetext{
${ }^{27}$ Wawancara dengan Andi Rachmad seorang akademisi Fakultas Hukum Universitas Samudra

${ }^{28}$ Wawancara dengan Brigadir Zamzami Penyidik Polres Langsa

29 Wawancara dengan Brigadir Zamzami Penyidik Polres Langsa

30 Sofyan Syafri Harahap, 2001, Budgeting Penganggaran: Perencanaan Lengkap Untuk Membantu Manajemen, Edisi Pertama, Cetakan Kedua, Jakarta, Raja Grafindo Persada, hal 14
} 
2. Koordinasi

Koordinasi adalah kegiatan yang dilakukan oleh berbagai pihak yang sederajat untuk saling memberikan informasi dan bersama mengatur atau menyepakati sesuatu, sehingga di satu sisi proses pelaksanaan tugas dan keberhasilan pihak yang satu tidak mengganggu proses pelaksanaan tugas dan keberhasilan pihak yang lainnya.

Koordinasi dilkakukan atas izin pimpinan kepada staf yang berada dibawah kepemimpinannya, maka dalam hal ini untuk memberikan informasi harus wajib memberitahukan terlebih dahulu atasan terkait untuk memberikan jawaban kepada orang lain.

Upaya yang harus dilakukan dalam penegakan hukum terhadap pihak Humas RSUD Langsa yaitu memberikan sanksi bagi setiap orang atau dokter yang membuka rekam medis pasien dimana dalam hal tanggungjawabnya merupakan kewenangan dari pada Direktur RSUD Langsa, jadi dalam hal ini penanganan dari segala yang timbul dari staf maupun dokter di RSUD dalam hal rekam medis harus saling adanya koordinasi kepihak atasan langsung agar dalam hal penyalahgunaan kewenangan dapat terkoordinasi dengan baik.

\section{SIMPULAN}

1. Dalam Undang-undang Nomor 29 Tahun 2004 tentang Praktek Kedokteran tidak di perbolehkan bagi seorang dokter maupun pihak terkait kesehatan yang membuka rekam medis pasien yang mempublikasikan kerahasiaan pasien yang sudah dijamin oleh perundang-undangan .

2. Penegakan hukum terhadap seseorang yang membuka rekam medis melalui media Humas RSUD Langsa dinilai tidak efektif dikarenakan apar penegak hukum dalam hal ini tidak serius dalam menangani kasus yang seharusnya dapat di pidanakan menurut ketentuan perundang-undangan.

3. Hambatan dalam penegakan hukum di RSUD Langsa yaitu masih adanya timpang tindih hukum yang dilakukan oleh aparat kepolisian sehingga penegakan hukum tidak dapat dilaksanakan secara adil dan adapun upaya yang dilakukan dalam penegakan hukum terhadap pihak RSUD Langsa yang membuka rekam medis yaitu dengan cara adanya pengawasan dan koordinasi antara pimpinan dan staf di RSUD Langsa.

\section{SARAN}

1. Disarankan kepada aparat penegak hukum agar dalam mengatasi kepastian hukum yang ada di wilayah hukum polres langsa agar serius dalam menangani kasus-kasus yang dapat merugikan masyarakat agar tercapainya cita-cita hukum.

2. Disarankan kepada aparat penegak hukum agar dalam penegakan hukum tidak tumpang tindih dan bersifat keterbukaan terhadap public agar tidak salah dalam menafsirkan hukum. 
3. Disarankan kepada pemerintah kota langsa khususnya RSUD Langsa agar dalam menjalankan pelayanan terhadap pasien agar dapat saling mengawasi institusi terkait agar tidak salah dalam menjalankan roda pelayanan bagi masyarakat umum.

\section{DAFTAR PUSTAKA}

\section{Buku}

Amiruddin dan Zainal Asikin, 2010, Pengantar Metode Penelitian Hukum, Jakarta, Rajawali Pers

Asmawi, 2006, Filsafat Hukum Islam, Surabaya, eLKAF Press

Departemen Kesehatan RI, 1997, Pedoman Pengelolaan RM Rumah Sakit Di Indonesia, Dirjen Pelayanan Medik, Jakarta

Ery, Rustiyanto, 2010, Statistik Rumah Sakit Untuk Pengambilan Keputusan, Edisi Pertama, Yogyakarta, Graha Ilmu

Dikutip oleh Teguh Prasetyo dan Abdul Halim, 2012, Teori, dan Ilmu Hukum, Jakarta, Raja Grafindo

Mukti Fajar dan Yulianto Achmad, 2012, Dualisme penelitian hukum normatif dan Empiris, Yogyakarta, Pustaka Pelajar

Rony Rahman Nitibaskara, 2000, Tegakkan Hukum Gunakan Hukum, Jakarta, Kompas

Said Sampara dkk, 2011, Pengantar Ilmu Hukum, Yogyakarta, Total Media

Soerjono Soekanto, 2006, Pengantar Penelitian Hukum, Jakarta, Universitas Indonesia (UIPress)

Sofyan Syafri Harahap, 2001, Budgeting Penganggaran: Perencanaan Lengkap Untuk Membantu Manajemen, Edisi Pertama, Cetakan Kedua, Jakarta, Raja Grafindo Persada

Sudikno Mertukusumo, 2009, Penemuan Hukum, Yogyakarta, Liberty

\section{Jurnal}

Gunther Teubner, Subtantive and Reflexsive Elements in Modern Law, Law and Social Review, Volume 17 Nomor 2.

Tyan Ferdiana Hikmah, dkk, 2019, Protection of Human Right for Pregnant Women in Implementing HIV/AIDS Screening for Prevention of HIV/AIDS transmission from mother to Child in Bantul District Health Center, SOEPRA Jurnal Hukum Kesehatan, Vol. 5 No. 1

Http://www.hukumonline.com/klinik/detail//t51fe16f7d4473/hak-pasien-dan-keluarganyaatas-rekam-medis

KBBI, http://kbbi.web.id/manfaat

Peraturan Perundang-Undangan

Undang-Undang Nomor 29 Tahun 2004 tentang Praktik Kedokteran.

Undang-Undang Nomor 36 Tahun 2014 tentang Tenaga Kesehatan 